\title{
Uncommon etiology of right atrial tumour - extension of thyroid cancer
}

\author{
Enikő Havránková', Emőke Šteňová, Ingrid Olejárová' \\ ${ }^{1}$ Department of Anaesthesiology and Intensive Care, National Institute of Cardiovascular Disease, Bratislava, Slovakia \\ $21^{\text {st }}$ Department of Internal Medicine, Comenius University, Bratislava, Slovakia
}

Havránková E, Šteňová E, Olejárová I. Uncommon etiology of right atrial tumour - extension of thyroid cancer. Cor Vasa 2011;53:729-730.

\begin{abstract}
Direct tumour extension into the right atrium in thyroid cancer is extremely uncommon. We report the case of an 80-year-old woman with echocardiography diagnosed in the right atrial mass. A large thyroid tumour with extension into the right jugular vein (JV), the superior vena cava (SVC) filling the right atrium was revealed by magnetic resonance imaging (MRI). Percutaneous fine-needle aspiration biopsy led to carcinoma being strongly suspected. The massive intravascular invasion and age of the patient contra-indicated surgical resection. Key words: Right intra-atrial tumour - Thyroid cancer - Echocardiography
\end{abstract}

Havránková E, Šteňová E, Olejárová l. Uncommon etiology of right atrial tumour - extension of thyroid cancer. Cor Vasa 2011;53:729-730.

Priame prerastanie karcinómu štítnej žl'azy do pravej predsiene je vel'mi zriedkavé.

Prezentujeme prípad 80-ročnej pacientky s echokardiografickým nálezom tumoróznej masy v pravej predsieni. Pomocou magnetickej rezonancie bol potvrdený rozsiahly tumor štítnej žlazy s prerastaním do pravej jugulárnej vény, vena cava superior a pravej predsiene s útlakom okolitých štruktúr mediastína. Perkutánna aspiračná biopsia štítnej žlazy bola vysokosuspektná pre nález karcinómu štítnej žlazy. Vzhl'adom k vel'kému rozsahu patologického procesu s prerastaním do okolitých štruktúr a veku pacientky bolo chirurgické riešenie kontraindikované.

Klúčové slová: Tumor pravej predsiene - Karcinóm štítnej žlazy - Echokardiografia

Address: MUDr. Enikő Havránková, Department of Anaesthesiology and Intensive Care, National Institute of Cardiovascular Disease, Bratislava, e-mail: kardio@afw.sk

\section{Introduction}

Lesions most commonly presenting as cardiac mural masses include myxomas, sarcomas, metastatic lesions and mural thrombi. ${ }^{1}$ Primary tumours of the heart are rare. Seventy-five percent of these tumours are benign and $50 \%$ are myxomas. Metastatic tumours of the right atrium usually arise from the abdomen and pelvis. The main mechanism of intracardiac tumour spread is extension of the tumour along the inferior vena cava (IVC) into the right atrium. This mechanism is described most frequently in renal cell carcinoma, Wilm's tumour, hepatoma and leiomyoma. ${ }^{2}$ Thyroid carcinomas with extensive tumour thrombus in the atrium are rare. We present a patient who had a thyroid carcinoma with extensive continuous tumour thrombus in the right jugular vein (JV), superior vena cava (SVC) and right atrium.

\section{Case Report}

An 80-year-old woman with a history of hypertension, ischaemic heart disease, euthyroid auto-immune nodular goitre was referred to our hospital with the signs and symptoms of vena cava superior syndrome. At the time of admission, she was dyspnoeic with palpitations. The patient had had a head and neck oedema in the mornings for one month.

Physical examination revealed face erythema, cyanotic lips, bilateral jugular venous distension, dilated veins over the upper body surface, protodiastolic gallop at the apex, accentuation of the secondary sound in the pulmonary area, mild bilateral leg oedema. The electrocardiogram (ECG) revealed a sinus tachycardia, ST segment depression in leads $\mathrm{V}_{3-6}$, diffuse low voltage. The chest radiograph showed a dislocation of the right upper mediastinum. Transthoracic echocardiography showed a right atrial mass of $70 \mathrm{~mm}$ in diameter, filling the entire chamber, which intermittently obstructed the right ventricular outflow tract, and tumorous masses were detected between the right ventricle and the ascending aorta (Figure 1). A computed tomography (CT) scan demonstrated a non-homogeneous soft-tissue mass in the upper anterior mediastinum - extension of the right thyroid lobe of size $55 \times 50 \times 90 \mathrm{~mm}$, compressed trachea, involvement of the right JV, SVC and right atrium mass of size $45 \times 35 \times 90 \mathrm{~mm}$. The magnetic resonance imaging 


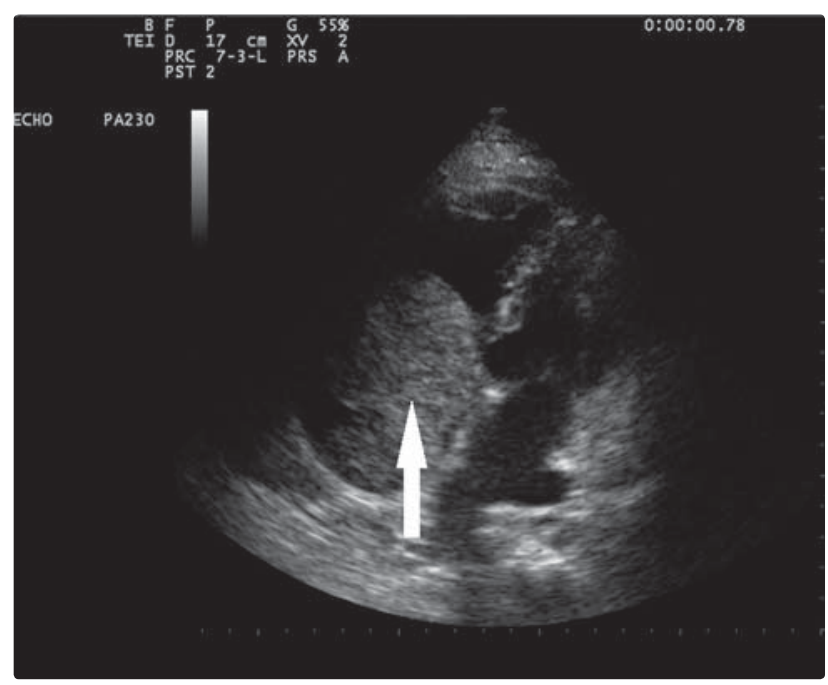

Figure 1 Transthoracic echocardiography showed a right atrial mass filling the whole chamber

(MRI) scan shows bilateral pleural and pericardial effusion, a large retrosternal thyroid tumour with extension between brachiocephalic veins causing dislocation of truncus brachiocephalicus, which extended into the SVC and fills the whole of the right atrium (Figure 2). Laboratory tests showed a normal blood count and a mild decrease in thyroxine; the thyroid-stimulating hormone was within the normal limits. The levels of thyroglobulin and anti-thyroglobulin antibodies were very high. A percutaneous fine-needle aspiration biopsy of the tumour was performed. Microscopically, the tumour was composed of cells with nuclear polymorphism and marked hyperchromatosis indicate a follicular proliferation with a strong suspicion of carcinoma. Open surgical biopsy was not indicated due to the high risk of the operation due to the location of the tumour mass being close to the major vessels of the upper mediastinum.

The patient was considered to be inoperable due to the huge and massive invasive extension of the tumour into

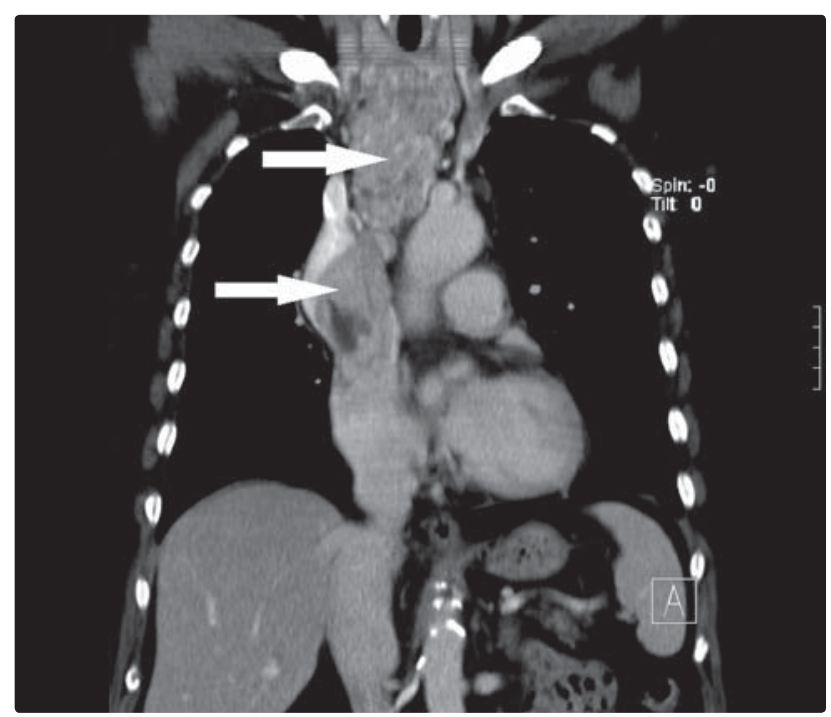

Figure 2 MRI scan shows large retrosternal thyroid tumor with extension into the superior vena cava and fills the whole right atrium the heart and vessels; radiotherapy was not recommended because of the high risk of embolisation. Only symptomatic treatment was indicated.

\section{Discussion}

Cardiac tumours are relatively rare. The primary tumours of the heart are tumours arising from the normal tissues that make up the heart. This is in contrast to secondary tumours of the heart, which are typically either metastatic from another part of the body, or which infiltrate the heart via direct extension from the surrounding tissues. Direct tumour extension into the right JV and the right atrium in thyroid cancer is extremely uncommon. In the literature, about twenty cases have been reported, with eight cases requiring surgical resection. ${ }^{3} \mathrm{CT}$ should be performed in patients with the symptoms and signs of SVC obstruction to differentiate intraluminal extension or extrinsic compression in thyroid cancers and assess the operability and surgical approach of intravascular extension. ${ }^{4}$ Aggressive surgery is acceptable and justified in advanced well-differentiated thyroid cancer to decrease the probability of local recurrence and to prevent tumour embolism. It also provides a better basis for effective radio-iodine therapy by reducing the tumour mass and hence offers the best hope for prolonged survival. ${ }^{3}$

In our case, surgical intervention was not indicated because of the age of the patient and the expansive tumour with infiltration of the great vessels. Age and the high risk of embolisation were the reasons why palliative radiotherapy was not recommended. Patients with an extensive tumour thrombus generally have poor prognoses and high mortality.

\section{Conclusion}

Cardiac tumours are rare pathological findings of echocardiography examination. CT and MRI scans are needed in differential diagnosis and staging of the tumour. In the case of superior vena cava syndrome caused by thyroid carcinoma, aggressive surgery has to be performed because of the direct primary tumour invasion and extended tumour thrombus. Without surgical intervention, the prognosis for patients is very poor.

\section{References}

1. Bruke A, Virmani R. In: Tumours of the heart and great vessels: Atlas of Tumour Pathology. $3^{\text {rd }}$ series, fascicle 16. Washington, DC: Armed Forces Institute of Pathology 1995:171-177.

2. Errichetti A, Weyman AE. Cardiac tumours and masses In: Weyman AE. Principles and practice of echocardiography. $2^{\text {nd }}$ ed. Pennsylvania: Lea and Febiger; 1994:1166-1168.

3. Taib NA, Hisham AN. Follicular thyroid carcinoma with direct tumour extension into the great cervical veins and right atrium: is transcervical thrombectomy a safe option? Asian J Surg 2007;30:216-219.

4. Thomas S, Sawhney S, Kapur BM. Case report: bilateral massive internal jugular vein thrombosis in carcinoma of the thyroid: $\mathrm{CT}$ evaluation. Clin Radiol 1991;43:433-434.

Došlo do redakce: 19. 4. 2011

Prijato: 20. 9. 2011 